\title{
The Policy Processes of Agricultural Land Protection for Sustainable Food Sovereignty
}

\author{
Muhammad Kamil ${ }^{1}$ \\ $\left\{\right.$ kamil@umm.ac.id $\left.{ }^{1}\right\}$ \\ Universitas Muhammadiyah Malang ${ }^{1}$
}

\begin{abstract}
This paper is about to examine the political processes of agricultural land protection policy as a strategy to minimize land. The conversion of agricultural land into non-agricultural land have an impact to the ecological and economic conditions of the society in Batu. Collaborative governance is a strategy to identify of interaction between government actors and stakeholders in the political process of protecting agricultural land in Batu. Land management as an alternative to ensure the optimization of planning policies for the protection of agricultural land in anticipation of the food crisis, safeguarding and preserving productive agriculture, and as an environmental buffer. Coordination and synergy in monitoring and evaluation by actor governance towards the planning and implementation process of land protection policies are carried out routinely as an effort to realize sustainable development.
\end{abstract}

Keywords: Policy Process, Transfer of Agricultural Land Functions, Food Sovereignty

\section{Introduction}

The agricultural sector has a very important role in the national economy [1]. Attention to sustainable development starts from R. Malthus's concern over land availability in the UK due to rapid population growth in 1798. Economic growth is very limited by the availability of natural resources [2] The availability of agricultural land is an issue that is not finished being discussed. Wide problem of agricultural land that has experienced embedding and limited printing of new land results in land conversion. Transfer of land function occurs dynamically and changes lead to the increasing population in Batu. Changes in the process of using land functions are inversely proportional to the food needs of Batu City. Management of resources to produce basic needs and improve environmental quality is the responsibility of the State and society [3]. Land conversion determination is caused by the scarcity of land and water resources and the dynamics of sustainable agricultural development [4].

The problem of land depreciation because of the increase in population and land-use change caused by the conversion of agricultural land into non-agricultural land [5]. Indonesian rice imports in the period of January to August 2013 reached 300,171 tons, and rice imports in 2014 increased to 669,395 tons. This is comparable to Batu as an International tourism center. In 2015 tourists visited as many as 3.5 million people and increased to 4.7 million people in 2017. In the last 10 years, the area of agricultural land has decreased by 11.5 percent. In 2003 the area of agricultural land reached 2,681 hectares and in 2013 it recorded and reached 2,373 hectares. Most of the agricultural land functions as residential areas, restaurant and business hotels. 
Regional spatial arrangements are able to strengthen food security capacity by increasing agricultural production and affecting spatial patterns and land use. In order to realize this, sufficient land resources are needed to anticipate food insecurity. Land conversion control is a system that involves regulations and actors [6]. Therefore, the development and development of tourism must continue to pay attention to the environment, so that it can provide protection to important areas such as protected forests, water sources and agricultural land. The absence of rules in the development of tourism, the direction of tourism development will shift to the periphery, especially agriculture.

The transfer of land function that continues to occur is a logical consequence of the development strategy that is only oriented to economic growth in a fast time called the exclusion of farmers. Farmer exclusion can occur because of several things such as the pressure of development regulations made by the government through the Spatial Plant (RTRW); legitimacy of development, modernity, civilization and environment; a market that works as a controller of economic activities carried out on land and people; and coercion or force against farmers who make them detached from the land that has been living it. Farmer exclusion has an impact on the welfare of farmers in terms of sources of livelihood, the loss of farmers' access to agricultural land forces farmers to choose the main livelihoods other than farmers [7]

The impact of the conversion of agricultural land can cause a decrease in food production. Transfer of land functions can be controlled by enforcing existing regulations and protecting the transfer of land functions for agricultural development. Therefore, the policy of controlling the conversion of agricultural land requires the existence of linkages of missions, synergies and collaboration between agencies in order to integrate various interests in the framework of controlling agricultural land that takes into account the preservation of regional functions and land use to realize food security and independence in Batu.

\section{Methodology}

This research uses qualitative descriptive research. That is, finding, uncovering, and carefully exploring the facts contained in a specific problem [8] regarding the policy of protecting agricultural land in Batu. The focus in this study is to explore collaboration to create synergies in policies in Batu Government, how the state works and the involvement of stakeholders in the decision-making process and protection of agricultural land in realizing sustainable development [6]. The source of the data is processed from primary data obtained from the Batu government and secondary data through interviews [9] with policymakers that are directly related to the policy of protecting agricultural land and stakeholders involved in the decision-making process. Secondary data in this study seeks to strengthen primary data, namely from legislation and or regulations that apply to the protection of sustainable food agricultural land (both regulations from the Central Government, East Java Provincial Regulation or the Batu Regional Regulation).

\section{Result and Discussion}

\subsection{Planning for Sustainable Agriculture Land Protection Policy in Batu}

The logical consequence of government policy to branding Batu into an International Tourism City has led to an increase in the number of modern tourist destinations and the number of tourist visits. In 2016 the number of modern tourism objects amounted to 6 , and tourist visits from 2013 to 2014 increased by 63,970 tourists. Construction of tourism 
accommodation causes agricultural land in Batu to continue to be pushed so that many experience land conversion. Regulatory planning is limited to the preparation of various studies needed for the formulation of academic texts, namely mapping of land fertility, the balance sheet of strategic environmental studies resources. Undang-undang No. 41 Tahun 2009 is the basis for preparing the regulation.

Factors that encourage the conversion of agricultural land as follows: (1) Increasing the need for non-agricultural land; (2) increasing population growth; (3) The insistence on the need to live economically; (4) High land fragmentation; (5) Environmental degradation due to excessive use of fertilizers and irrigation water pollution; and (6) the budget allocation for the small agricultural sector because the priority of development is prioritized on the nonagricultural sector.

East Java Province Long Term Development Plan (RPJP) 2005-2025 that the government (district/ city) must develop a modern agribusiness-based economy, namely the development of food crops, horticulture, plantations, fisheries and livestock. To protect agricultural land in Indonesia from changes in use and function, the government issued a policy in the form of protection of sustainable agricultural land through Undang-undang No. 41 Tahun 2009 concerning Protection of Sustainable Food Agriculture Land (LP2B).

Table 1. Land Area Development of Batu

\begin{tabular}{ccccccc}
\hline $\begin{array}{c}\text { Types of } \\
\text { Agricultural } \\
\text { Land }\end{array}$ & $\mathbf{2 0 1 1}$ & $\mathbf{2 0 1 2}$ & $\mathbf{2 0 1 3}$ & $\mathbf{2 0 1 4}$ & $\mathbf{2 0 1 5}$ & $\mathbf{( \% )}$ \\
\cline { 2 - 7 } & 2516 & 2436 & 2373 & 2481 & 2480 & -1.4 \\
\hline $\begin{array}{c}\text { Irrigated Rice } \\
\text { Fields (Ha) } \\
\text { Farms } \\
\text { /agriculture }\end{array}$ & 14858.58 & 14717.69 & 14732.72 & 14623.82 & 14386.93 & -3.17 \\
$\begin{array}{c}\text { Dry land(Ha) } \\
\text { Total }\end{array}$ & $\mathbf{1 7 , 3 7 4 . 5 8}$ & $\mathbf{1 7 , 1 5 3 . 6 9}$ & $\mathbf{1 7 , 1 0 5 . 7 2}$ & $\mathbf{1 7 , 1 0 4 . 8 2}$ & $\mathbf{1 6 , 8 6 6 . 9 3}$ & $\mathbf{- 4 . 6}$ \\
\hline
\end{tabular}

Source: Data of the Agriculture Office of Batu; processed

As an effort to fulfill food needs, the government formulates a food sovereignty policy through the 2015-2019 Government Strategic Plan. The development of agricultural land area in Batu experienced shrinkage due to the conversion of agricultural land into non-agricultural land or built land (for the construction of tourist attractions, offices, housing and business areas). As a result many people who transformed from farmers to workers in the tourism sector. This makes farmers in Batu do not have future generations and convert their agricultural land into housing or lodging.

The policy of broad ownership / ownership has failed because it has weaknesses in the level of administration, the cause is the difficulty faced in identifying subjects and objects of land that exceed the provisions, so that the policy cannot run as expected. The progressive tax policy, although it does not have a legal umbrella, is still being carried out and experiences various obstacles such as difficulties in identifying tax objects, and there is no guarantee of redistribution of ownership / land tenure. While the failure of agrarian reform is due to the lack of a database and the lack of proactive involvement of stakeholders in policy implementation. 
Table 2. Schemes for Sustainable Use of Food Farming

\begin{tabular}{|c|c|c|}
\hline Scenarios & Core Land & Buffer Land \\
\hline Firstschemes & $\begin{array}{l}\text { Irrigation that enter the area } \\
\text { with the designation of } \\
\text { irrigated wetland agriculture } \\
\text { Irrigated }\end{array}$ & $\begin{array}{l}\text { fields that enter the area with } \\
\text { agricultural land designation } \\
\text { and non-irrigated agricultural } \\
\text { land }\end{array}$ \\
\hline $\begin{array}{l}\text { Second } \\
\text { Scheme }\end{array}$ & $\begin{array}{l}\text { Irrigated rice fields that enter } \\
\text { the area with irrigated } \\
\text { wetlands, non-irrigated } \\
\text { agricultural land and other }\end{array}$ & $\begin{array}{l}\text { uses Irrigated rice fields that } \\
\text { are in an area with other uses } \\
\text { consist of tourism areas }\end{array}$ \\
\hline Scheme Third & $\begin{array}{l}\text { Irrigated rice fields that enter } \\
\text { the area with the designation } \\
\text { of irrigated wetland } \\
\text { agriculture, non-irrigated } \\
\text { agricultural land and other } \\
\text { uses (all designations are in } \\
\text { Bumiaji sub-district) }\end{array}$ & $\begin{array}{l}\text { Irrigated paddy fields that } \\
\text { enter wetland areas with the } \\
\text { dry land allotment and other } \\
\text { uses }\end{array}$ \\
\hline
\end{tabular}

To prepare the spread of sustainable agricultural land, Batu City Government has identified and analyzed the potential of the land food agriculture Sustainable and land mapping. The output of this policy planning activity is in the form of a Sustainable Food Farming Land Scenario. In table 1, there are three schemes for Sustainable Food Farming Utilization which can be considered to be implemented in Batu. Criteria for agricultural land that will be designated as Sustainable Food Farming Land, namely compliance with the Regional Spatial Plan (RTRW); distance to roads, rivers and irrigation channels; distance to settlements and other land uses; area of paddy fields; and agricultural land that has been certified as a certificate of land for farmers/ eternal land.

\subsection{Collaborative Process in Identifying Issues of Transfer of Functions of Batu}

Biophysical characteristics of natural resources also influence the choices available to actors [10]vas well as the relationships between community groups. The most popular is the dependence of two community groups in the downstream and upstream watersheds (DAS). The fact that the conversion of agricultural land to non-agricultural land is increasing from year to year shows that the conversion of agricultural land is not easy to overcome, one of which is the impact of tourism development activities and infrastructure carried out. Although the regulation of Sustainable Food Agriculture Land Protection must be immediately determined, the tendency of the transfer of function can be controlled through a series of policies that give priority to the agricultural sector as one of the important sectors in development.

The most popular policy instrument is the legal approach, economic approach and coercion approach in achieving collaboration between the government and the community. In principle, the Batu government must implement regional development management schemes based on land potential, biophysics, development trends, RTRW directives, urban agglomeration, availability of access to public services, and population density and growth in each subdistrict. The aim is to realize land use optimally, especially for the interests of Sustainable Food Agriculture Land Protection. 
Highlighted political contestation based on data and concrete evidence and not just ideology in policy formulation. Policy-based evidence in the political process is not evidencebased policy [11]. In policy-based evidence, the Batu City government tries to find out what works and what needs to be synergized towards policy objectives. The issue regarding the Batu city government to achieve food security and the conversion of agricultural land, has led the government to issue policies on the protection of sustainable food agricultural land. Mandate from Undang-undang No. 41 Tahun 2009 concerning the protection of LP2B authorizes the determination and planning of LP2B to the provincial and regional governments. Identification of the issue of the conversion of agricultural land to nonagricultural land is an initial attempt to control the direction of policy. Identification of land use change is done by collaborating with various stakeholders as a strategy to achieve policy success. The issue of land conversion due to various factors, First because of the need for nonagricultural land. Both the needs of farmers economically so as to make farmers convert agricultural land into non-agriculture (home stay and sell land), Third population growth and environmental degradation.

The rise of the conversion of agricultural land in Batu which has resulted in reduced rice land has made the needs of the Batu community towards LP2B policy increasingly urgent. The purpose of the LP2B policy is the answer to the problem of the conversion of agricultural land in Batu. LP2B's protection policy is not only aimed at suppressing or controlling the transfer of agricultural land functions, but to protect the area and food crops sustainably; guarantee the availability of sustainable food agricultural land; realize independence, resilience and food sovereignty; protect ownership of farmer food owned by farmers; increasing prosperity and welfare of farmers and the community; increasing the protection and empowerment of farmers; increase the provision of employment for a decent life; maintain ecological balance; and realize agricultural revitalization.

The collaboration process in the policy of protecting agricultural land in Batu City has at least three stakeholders involved in the planning process, Regional Planning and Development Agency/ Bappeda (Economic Development Planning, Natural Resources, Infrastructure and Regional Affairs), Agriculture Agency (Program and Reporting Sub Division, and Food Crops and Horticulture ) who acts as a technical agency who has a data field location and will be in direct contact with farmers, and the Public Works, Bina Marga and Irrigation (Spatial Planning and SDA) Office which has data on rice field irrigation systems and spatial utilization.

The Batu government framework in the policy process runs in line with the linear and modern rational models, collaboration process is carried out vertically and horizontally as a form of synergy between stakeholders in enforcing regional spatial planning policies. Through an exploration of the problem of land conversion as an arena of collaboration and synergy, certainty of rights or natural resources can be controlled by the Batu government and can be managed together with the community as a form of fostering public awareness of the environment. The assumption is that information and policy alternatives are logical frameworks if explored by perpetrators, namely from the Department of Environment, the Department of Agriculture, and the Community.

Regional Planning and Development Agency (Bappeda) as a conceptor in the field of planning and development for the protection of agricultural land is able to regulate, measure and control the process of making and implementing policies. The rational model seeks to remove the political influence of the entire policy-making process. Because it is not speculative, the policy-making process with the rational model is claimed to be free from 
probable bias and prejudice, based on scientific empiricism, decision making guided by proven facts and guided by experimental results.

Collaborative planning process carried out by Regional Planning and Development Agency (Bappeda) regarding LP2B policy began with the planning of the LP2B location contained in the Batu Spatial Plan, the determination of the location of LP2B in the Batu Spatial Detail Plan (RDTR) and the preparation of regional regulations on LP2B. In the preparation of the Batu RDTR, contained in the regional regulations on the City Region Section (BWK), Regional Planning and Development Agency is currently still in the stage of drafting the respective regional regulations of the BWK. In the BWK regulation, the location of LP2B will be included by name by address, so that to be able to implement LP2B policy in Batu still requires a long time, considering that BWK I and II regulations are still proposed to the governor of East Java, while the regional regulation for BWK III is still experiencing substance revision.

To accelerate the preparation of RDTR which includes the location of LP2B by name by address, the land data collection by name, ownership, and location must be immediately submitted by the Agriculture Service. As a technical service, the Agriculture Service will have more contact with the community, ranging from socializing to the community regarding policies on LP2B, data collection of land area in each village, and data collection on land ownership which will later be designated as LP2B. Coordination is also carried out with Field Extension Officers (PPL) to find out which agricultural lands have the potential to be used as LP2B. The Program and Reporting Sub Division has a role in preparing LP2B potential lands that meet the requirements, while the Food Crops and Horticulture Fields play a role in determining the types of food crops suitable for planting in Batu agricultural land and providing information on food crop production in Batu.

The spatial planning and natural resources sector, the Public Works Office, Bina Marga and Irrigation in this policy become the technical service that deals with irrigation and irrigation systems. The Spatial Planning Field will provide input on determining the location of LP2B to be in accordance with the Batu area planning plan, while the natural resources, especially the irrigation sector, plays a role in providing data on rice field irrigation systems in Batu. Data regarding the irrigation system is the data needed at the time of the preparation of the LP2B planning, considering that the LP2B stipulated in Batu is an irrigated rice field. Together with the Department of Agriculture, the Public Works Service shared data so that the data of the rice fields would be in accordance with the requirements of the LP2B. Data from the Department of Agriculture and Department of Public Works are used as references for Bappeda to carry out planning activities for LP2B locations.

3.3 Planning Collaboration Action: DominationActorinagenda settingPolicyprotection of Sustainable Food Farming Land

The importance of setting agendas and identifying alternative actions as an important part of individual strength and the dominance of actors to establish [12]. Collaboration in planning the preparation of the LP2B agenda, the dominant actors are Bappeda and the Agriculture Agency. As a technical service, the role of the Department of Agriculture is greater than that of the Public Works Agency, because the Agriculture Service is an agency that deals directly with farmers, so that all kinds of socialization activities are carried out by the Agriculture Service. Employment relations and conflicts of interest between supervisors and supervised ones or between policy makers and subjects affected by policy in general have not been taken seriously. A statement is a necessity more important than the application of a code of ethics. The active Regional Planning and Development Agency (BAPPEDA) official must be 
independent and therefore there is no problem when he has consultations in his authority without a conflict of interest.

The decision on the implementation of licensing is not focused on the criteria and technical data as a matter of consideration and fairness and broad implications for the public, but rather on negotiations on the basis of mutual assistance. Such relations are an ethical awareness of Regional Planning and Development Agency Bappeda and Agriculture Department to realize ethical competency and efficiency in institutionalization. This makes the community not the subject of development because the characteristics of society are generally unknown, so the subject of development shifts from the community to physical resources such as land area, location of activities, potential natural resources and others. Society is considered an object not a subject.

There is almost what gap is generated in the implementation of the program with what is needed by the community as well as administrative matters and accountability of the Agriculture and Regional Planning and Development Agency (Bappeda) Office. This is because coordination is only carried out by the Department of Agriculture and Regional Planning and Development Agency (Bappeda), Public Works Services only a role in providing data on irrigation systems. Regional Planning and Development Agency (Bappeda) as the LP2B planning center coordinates with the Regional Planning and Development Agency Provincial (Bappeda) and also coordinates with the technical service in Batu. Regional Planning and Development Agency Provincial provides support to the City/ District government to accelerate the implementation of LP2B policies. The entry of Batu as one of the cities designated as a city that has LP2B must immediately determine the location of LP2B both in the Batu City Spatial Plan or in the Batu RDTR.

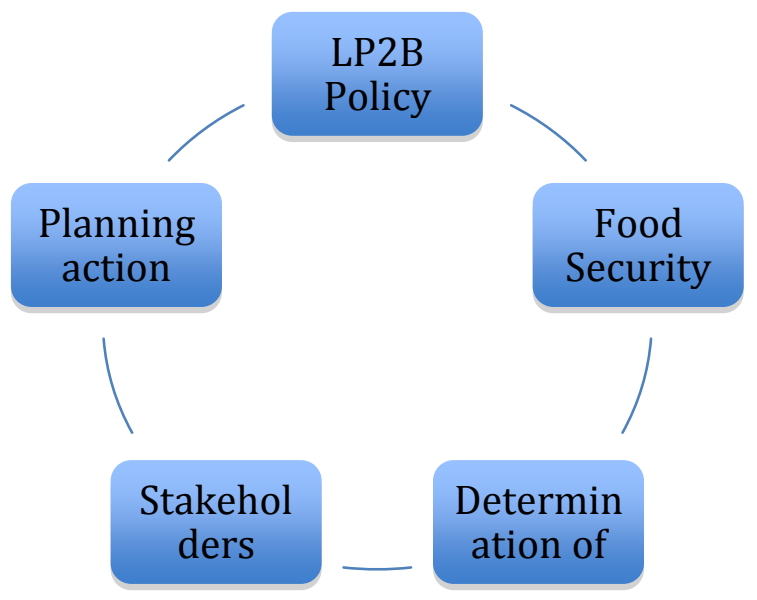

Figure 1. Synergy about Sustainable Agriculture Land Protection in Batu

In explaining the synergy, data related to agricultural land in Batu from the Agriculture services are needed, and agricultural irrigation system data from the Public Works servicec. Whereas with the technical service, Bappeda coordinates more often with the Agriculture Services. This is because as an agency that has a wide area of rice fields and the utilization and become an agency that deals directly with farmers. In addition, agricultural land is indeed inseparable from the agricultural service, because the agricultural service has authority over 
policies on agriculture, such as the protection of LP2B. Whereas the Public Works Agency is not an actor that dominates the LP2B policy, because its role in this policy is only limited to sharing data conducted with Bappeda, which is about rice irrigation system data in Batu.

LP2B's policy in Batu entered into the initial process of public policy, namely the preparation of a policy agenda. In the agenda-setting process there are two activities that take place, namely political activity and intellectual activity. Both are interrelated because intellectual activity is an activity used to formulate problems related to the conversion of agricultural land, while political activity will bring the problems that have been found to be followed up by formulating LP2B policies. The needs of the Batu community for LP2B policy as a solution to overcome the problem of the conversion of agricultural land become urgent when the rice field continues to experience depreciation. In addition, the LP2B policy which is mandated by Undang-undang No. 41 Tahun 2009 made this policy one of the priority policies of the central and provincial governments, so that inevitably the district or city government must make LP2B policy as one of the policies that are included in the preparation of the policy agenda in the Batu government, and become a policy that must be implemented immediately.

In the agenda-setting process there is a process of identifying problems by actors to find out how far these problems threaten people's lives so that they need to be immediately discussed and formulated. Several actors began to be involved in the process of drafting the LP2B policy agenda in Batu, Batu Regional Development Planning Agency, the Agriculture Service and the Public Works Agency. In the process of planning and determining LP2B Problem recognition is carried out by all stakeholders relevant so that the stakeholders understand the characteristics of the problem and understand what role they should do. The activity of preparing the LP2B policy agenda in Batu itself includes the planning and designation process of LP2B in Batu.

Facilitative leadership in the planning process and the determination of LP2B in Batu is an attempt to find a solution to the problem. Coordination of the East Java Provincial Government and the Batu government (Bappeda, and the Agriculture Office) in 2010 as described in the previous chapter. Planning and determination were then carried out by the Batu government.

The preparation of agendas in Batu was carried out by coordinating stakeholders in the Batu government environment related to LP2B policy to determine the distribution of LP2B locations in Batu. The meeting produced the Batu RTRW document which contained the LP2B location. The RTRW was then ratified by the issuance of Mayor Regulation No. 7 of 2011 concerning the RTRW of Batu City 2010-2030, in that local regulation the location of LP2B was planned to spread in three sub-districts, so each sub-district had agricultural land which would be designated as sustainable food agricultural land, namely Batu District (Sisir Village and Temas Village), Bumiaji District (Giripurno Village and Pandanrejo Village) and Junrejo District (Pendem Village, Torongrejo Village, Beji Village, Mojorejo Village, Junrejo Village, and Dadaprejo Village). This location planning considers several things such as geographical conditions, cultural culture and functions of each BWK. Planning is carried out through coordination between Bappeda, the Agriculture Service, and the Public Works Office. The coordination can be in the form of formal and informal meetings and sharing of data related to agricultural land in Batu. As an agency that plans, Bappeda needs support and assistance from agencies as technical agencies that have various data related to agriculture, both land area and irrigation system. Therefore sharing data between stakeholders becomes an activity that must be carried out in order to realize LP2B planning in accordance with the mandate of the law. 


\section{Conclusion}

Issue of land conversion is due to various factors, first because of the need for nonagricultural land. Second, the needs of farmers economically so as to make farmers convert agricultural land into non-agriculture (home stay and sell land), Third population growth and environmental degradation. The emergence of issues that developed in the Batu community regarding agriculture became the problems faced by the government such as the conversion of agricultural land to non-agriculture, the development of tourism development, and the increase in population. The problem formulation process consists of several stages: problem search, problem definition, problem specification and problem recognition. The search for problems related to agricultural land conversion activities is carried out through the exploration of issues of conversion of agricultural land or the cause of the conversion of agricultural land in Batu.

In the process of preparing the agenda there are intellectual activities that involve the formulation of problems. Collaboration in Batu's sustainable agricultural land protection policy process through the current government framework follows a linear and modern rational model. Awareness of government ethics is a major need in the determination and implementation of policies. Society is no longer regarded as the subject of sustainable development but as an object, so that the community is not fully regarded as part of the natural ecosystem.

The process of collaboration with various stakeholders can be a key indicator of successful decision making. The process of identifying problems, dialogue and listening to opinions, to collaborative action planning carried out by the Batu city government (Bappeda and the Public Works Agency) and the community are the main benchmarks in achieving policy success. The sectoral system (program fragmentation) is a consideration in planning in determining the program. The main tasks and functions of government work units are more standard and determine the success of planning collaboration. Policy instruments and cooperation with Baappeda, the Agriculture Service and other work units are key to the success of sustainable agricultural land protection.

\section{References}

[1] M. et al. Mulyadi, Sustainable development: Social, Economic and Environmental Dimensions. Jakarta, 2015.

[2] Fauzi, Economics of Natural Resources and the Environment: Theories and Applications. Jakarta: Gramedia Library, 2006.

[3] Sabiham, Manajemen Sumber Daya Lahan dan Pertanian Berkelanjutan. Jakarta: Yayasan Obor Indonesia.

[4] E. Pasandaran, "Alternative policies for controlling land conversion in Indonesia," Agric. Res. Dev. J., vol. 25, no. 4, pp. 123-129, 2006.

[5] P. R. Nurianansyah, "Implementasi Kebijakan Pengendalian Alih Fungsi LahanPertanian di Kota Batu Sebagai kawasan Agropolitan," J. Kebijak. dan ManajemenPublik, vol. 3, no. 2, p. 72, 2015.

[6] Harjono, "Evaluation of Agricultural Land Conversion Control Policy in Kendal District. Thesis," Undip Semarang, 2005.

[7] E. W. Satria, "Ekslusi Petani Akibat Alih Fungsi Tanah Pertanian Di Wilayah Pinggiran Kota." Sekolah Tinggi Pertanhan Nasional Badan Pertanahan Nasional RI, pp. 3-4.

[8] M. Alston and B. Wendy, Research for social workers: An introduction to methods. 
Australia: Allen and Unwin, 1998.

[9] Hamidi, Qualitative Research Methods Practical Applications for Making Proposals and Research Reports. Malang: UMM Press, 2004.

[10] E. Schlager, A Compararison of frameworks, theories and models of policy processes. Westview Press, 1999.

[11] J. Kingdon, Agendas, Alternatives and Public Policies. New York: Harpers Collin, 1984.

[12] R. Sutton, “The Policy process: An overview. Worki." 